\title{
Genetic Analysis Using Partial Sequencing of Melanocortin 4 Receptor (MC4R) Gene in Bligon Goat
}

\author{
Latifah $^{\text {a }}$, D. A. Priyadia , D. Maharani ${ }^{\mathrm{a}}$, Kustantinah ${ }^{\mathrm{b}}$, \& T. Hartatik ${ }^{\mathrm{a}}$. \\ ${ }^{a}$ Department of Animal Breeding and Reproduction, Faculty of Animal Science, Universitas Gadjah Mada \\ ${ }^{b}$ Department of Animal Nutrition and Feed Science, Faculty of Animal Science, Universitas Gadjah Mada \\ Jalan Fauna No. 3, Sleman-Yogyakarta, Indonesia \\ (Received 25-04-2017; Reviewed 15-06-2017; Accepted 17-07-2017)
}

\begin{abstract}
Melanocortin 4 Receptor gene is involved in sympathetic nerve activity, adrenal and thyroid functions, and media for leptin in regulating energy balance and homeostasis. The aim of this research was to perform genetic analysis of MC4R gene sequences from Bligon goats. Fourty blood samples of Bligon does were used for DNA extraction. The primers were designed after alignment of 12 DNA sequences of MC4R gene from goat, sheep, and cattle. The primers were constructed on the Capra hircus MC4R gene sequence from GenBank (accession No. NM_001285591). Two DNA polymorphisms of MC4R were revealed in exon region (g.998A/G and g.1079C/T). The SNP g.998A/G was a non-synonymous polymorphism, changing of amino acid from methionine (Met) to isoleucine (Ile). The SNP g.1079C/T was a synonymous polymorphism. Restriction enzyme mapping on Bligon goat MC4R gene revealed three restriction enzymes (RsaI (GT'AC), Acc651 (G'GTAC_C), and KpnI (G_GTAC'C), which can recognize the SNP at g.1079C/T. The restriction enzymes may be used for genotyping of the gene target using PCR-RFLP method in the future research.
\end{abstract}

Keywords: MC4R, Bligon goat, genetic analysis, sequencing, SNP

\section{ABSTRAK}

Gen melanocortin 4 reseptor merupakan gen yang mempengaruhi aktivitas saraf simpatik, fungsi adrenal dan tiroid, dan sebagai media bagi leptin dalam meregulasi keseimbangan energi dan homeostasis. Penelitian ini bertujuan untuk melakukan analisis genetik sekuens gen MC4R pada kambing Bligon. Empat puluh sampel darah induk kambing Bligon telah diekstraksi. Primer didesain setelah dilakukan penyejajaran pada 12 sekuens gen MC4R dari kambing, domba, dan sapi. Primer didasarkan pada gen MC4R Capra hircus yang diambil dari Genbank (accession No. NM_001285591). Dua polimorfisme DNA gen MC4R teridentifikasi pada daerah ekson (g.998A/G dan g.1079C/T). Posisi SNP g.998A/G merupakan polimorfisme non-synonymous yang menyebabkan perubahan asam amino metionin (Met) ke isoleusin (Ile). Posisi SNP g.1079C/T menunjukkan polimorfisme synonymous. Pemetaan enzim restriksi pada gen MC4R kambing Bligon mengungkap tiga enzim restriksi (RsaI (GT'AC), Acc651 (G'GTAC_C), dan KpnI (G_GTAC'C)) yang dapat mengenali SNP pada g.1079C/T. Ketiga enzim restriksi tersebut kemungkinan dapat digunakan untuk penentuan genotipe menggunakan metode PCR-RFLP pada penelitian lanjutan.

Kata kunci: MC4R, kambing Bligon, analisis genetik, sekuensing, SNP

\section{INTRODUCTION}

Goat was one of the most common small ruminants that are reared by a small farmer in Indonesia. Some goat breeds in Indonesia are Kacang, Ettawa Grade (PE), Bligon, Kejobong, Gembrong, Marica, Samosir, Muara,

*Corresponding author:

E-mail: tety@ugm.ac.id and Bengal goats (Hartatik, 2014). The goat which has widely reared was Bligon goats. Bligon goat is breed produced by crossing local Kacang with Ettawa Grade goats and it has a blood profile over $50 \%$ of Kacang goat. The growth performance of goat is affected by genetic, environmental factors, and the interaction of both. Genetic quality needs to be improved to get a better performance of Bligon goat. Therefore, the basic genetic potential of the local goat breeds must be studied. Genetic factors encoding growth traits can be passed down to 
the offspring, so it can be used in livestock breeding programs. Over the past decades, molecular genetics have found candidate genes, one of which is a melanocortin 4 receptor.

Capra hircus melanocortin 4 receptor (MC4R) gene is located on chromosome 24, composed of one exon. Based on GenBank accession No. NM_001285591, Capra hircus MC4R gene sequence consist of 2,068 bp. It consisted of $386 \mathrm{bp}$ of $5^{\prime} \mathrm{UTR}$, one exon (exon 1) with corresponding $683 \mathrm{bp}$ of 3'UTR (NCBI, 2015). MC4R gene is part of a seven-transmembrane $\mathrm{G}$ protein receptor in the brain, especially the double in the hypothalamus (Dubern, 2015). MC4R gene is involved in sympathetic nerve activity, adrenal, thyroid function, media for leptin in regulating energy balance and homeostasis (Zhang et al., 2009).

The MC4R gene have been reported to have single nucleotide polymorphism and the change of amino acid due to the polymorphisms in mammals (Fontanesi et al., 2013; Liu et al., 2010; Zou et al., 2013; Wang et al., 2015; Jun et al., 2013). MC4R gene polymorphism have also been identified as genetic markers for ADG, FGR, back fat tickness, fatness, leanness, fat distribution, and feed intake in pig (Piorkowska et al., 2010; Galve et al., 2012; Fontanesi et al., 2013; Schroyen et al., 2015), life weight, ADG, carcass weight, back fat thickness, marbling, and dressing percentage in cattle (Zhang et al., 2009; Liu et al., 2010; Seong et al., 2011), body weight, body measurement, meat quality, back fat thickness, and loin-eye area in sheep (Zhang et al., 2009; Song et al., 2012; Zou et al., 2013; Wang et al., 2015) and body weight in Boer goat (Jun et al., 2013). However, no report on the MC4R gene study have been identified in Bligon goat. The rule of MC4R gene in many livestock species suggests that it may be an important genetic marker in Bligon goat.

Therefore, the aim of this study was to perform genetic analysis of MC4R gene sequences in Bligon goat.

\section{MATERIALS AND METHODS}

\section{Blood sampling and DNA Isolation}

The blood samples were collected from 40 Bligon does in Gunung Kidul, Yogyakarta. The blood samples were collected using vacutainer containing K3EDTA about $3 \mathrm{~mL}$ for each does through jugular veins. The blood samples were isolated using SYNC ${ }^{T M}$ DNA Extraction Kit (Geneaid, Taiwan). The sequence com- parison for picking the primer and for phylogenetic tree analysis used twelve MC4R genes from GenBank database (www.ncbi.nlm.nih.gov). Because of the limitation of MC4R gen sequence in goat, the sequences from various sheep and cattle were also used in this study. Sequence of intra-Bovidae species can be used as data comparison because of the genetic similarity between goat, sheep, and cattle for about 89\% (Gregorio et al., 2014).

\section{Primer Design and DNA Amplification}

The primer design method is based on Hartatik (2016). Primers were designed using oligoprimer primer3 (free online at http://primer3.ut.ee/) based on twelve MC4R GenBank sequences; acc. No. NM_001285591, JN107563.1， JN58091， NM_001126370.2， JQ710684.1， EU622853.2, NM_174110.1， FJ430565.1， EU366351.1, EU366349.1, AF265221.1, and EU366350.1. These primers were also used to confirm the single nucleotide polymorphisms position. The MC4R gene target was amplified using PCR (Polymerase Chain Reaction) method using two sets of primers (Table 1). BG1 and BG2 are PCR target in this study. A size of PCR target was 387 bp and 642 bp for BG1 and BG2, respectively. The target of BG1 is located in base 183-386 (5'UTR) and base 387-569 (exon $1)$, while the region of BG2 is located in base 924-1385 (exon 1) and base 1386-1565 (3'UTR). PCR was performed in the $30 \mathrm{~mL}$ total reaction volume, comprising $10 \mu \mathrm{L}$ of DDW, $1.5 \mu \mathrm{L}$ of primer $\mathrm{F}$ and $\mathrm{R}, 15 \mu \mathrm{L}$ of PCR kit (KAPPABIOSYSTEMS), and $2 \mu \mathrm{L}$ of DNA genome. DNA amplification was done by 35 cycles with the predenaturation temperature at $94^{\circ} \mathrm{C}$ for $3 \mathrm{~min}$, denaturation at $94^{\circ} \mathrm{C}$ for $30 \mathrm{sec}$, extension at $72^{\circ} \mathrm{C}$ for $30 \mathrm{sec}$, and followed by a final extension at $72^{\circ} \mathrm{C}$ for $10 \mathrm{~min}$.

\section{Sequencing}

The $30 \mu \mathrm{L}$ of PCR products were sequenced using the same primer (forward primer) for PCR target of BG1 (location in 5'UTR and exon; $n=40$ ) and BG2 (location in exon and 3'UTR; $n=10)$. Sequencing was performed by PT. Genetika Science, Indonesia.

\section{Genetic Analysis of MC4R Gene Sequences}

Genetic analysis was performed to identify the genetic variation of Bligon goat population and com-

Table 1. Two primer sets to identify SNP MC4R gene in Bligon goat

\begin{tabular}{|c|c|c|c|c|c|}
\hline Name & Sequence & Primer region & Location & Size & $\begin{array}{c}\text { Annealing } \\
\text { temperature }\left({ }^{\circ} \mathrm{C}\right)\end{array}$ \\
\hline \multirow[t]{2}{*}{ BG1 } & F: 5'-ATTTCCAAGTGATGCCGACC-3' & $5^{\prime} \mathrm{UTR}$ & $183-569^{a}$ & $387 \mathrm{bp}$ & $55.9^{\circ} \mathrm{C}$ \\
\hline & R: 5'- CTCCAACAAGCTGATGACCC-3' & Exon 1 & & & \\
\hline \multirow[t]{2}{*}{ BG2 } & F: 5'-TCGGGCGTCTTGTTCATCAT-3' & Exon 1 & $924-1565^{a}$ & $642 \mathrm{bp}$ & $57.8^{\circ} \mathrm{C}$ \\
\hline & R: 5'-CAAGACTGGGCACTGCTTCA-3' & 3'UTR & & & \\
\hline
\end{tabular}

Note: aReference sequeance GenBank accession no. NM_001285591 
pared to another goat breed. Genetic analysis consisted of identification of single nucleotide polymorphism, amino acid change, restriction enzyme mapping, and phylogenetic tree. The methods of SNP identification, amino acid change, and restriction enzyme mapping were described by Hartatik (2016). The sequences results from sequencing analysis (BG1 $=40$ samples and BG2= 10 samples) were then aligned using Bioedit software (ver 7.2.0) to identify the single nucleotide polymorphism, amino acid change, and restriction enzyme mapping. Phylogenetic tree analysis was done to infer the evolutionary relationship inter and outer species based on MC4R gene. It is performed by comparing the Bligon genotype with another goat breed and another Bovidae species. Phylogenetic tree was performed based on Kimura (1980) method using Mega 5.0 program (Maximum likelihood; bootstrap value 1000; TamuraNei parameters).

\section{RESULTS}

\section{Genetic Variation of MC4R Gene}

In this study, there were two primer namely BG1 and BG2 for amplification gene target of MC4R (Figure 1). Identification SNPs performed with comparing the Bligon goat sequence and two goat sequences were published in NCBI (NM_001285591 and JN 107563.1). As a result, three SNPs identified in the gene target (BG1 and BG2). Two SNPs were detected in BG1 and one SNP identified in BG2 (Figure 2). The SNP g.286G/C and g.303C/T were located in the untranslated region and the g.1515A/G was identified in the coding region (Table 2). The SNPs were not found in Bligon goat population. The allele $\mathrm{G}$ of g.1515A/G polymorphism encodes for a conservative isoleucine (Ile) while the allele A encodes for methionine (Met). However, those SNPs were not confirmed in between Bligon goat samples. In fact, the other two SNPs were found in the same of gene target (Figure 2).

Single Nucleotide Polymorphism (SNP) was screened by DNA sequencing. Two SNPs were found when primer BG2 was used, but none was found when using primer pair BG1 (Figure 3). Two SNPs were located in exon 1 region (g.998A/G and g.1079C/T). The SNP
g.998A/G was non-synonymous polymorphism that changed amino acid methionine (Met) to isoleucine (Ile). The SNP g.1079C/T changed the codon GGC to GGT. It was synonymous polymorphism and encoded the same amino acid (glycine) (Figure 4). While using DNA sequencing method, SNP g.998A/G and g.1079C/T were successfully genotyped. The SNP g.998A/G genotype formed GG and GA genotypes; the SNP at g.1079C/T produced two genotypes (CC and CT).

\section{Restriction Enzyme Mapping}

Based on restriction enzyme mapping using Bioedit ver. 7.2.0 software, there were 6 enzymes which recognized SNP region, consisting of 4 enzymes with 4-bases (FatI, HaeIII, NlaIII, and RsaI) and 2 enzymes with 6-bases (Acc651 and KpnI). There were 3 enzymes that produced large fragments $(>100 \mathrm{bp})$ and had a specific character (Table 3). Among 6 enzymes, there were 3 recommended enzymes for genotyping the Bligon goat (Table 4). The 3 recommended restriction enzymes cleavage the PCR product at the SNP g.1079C/T. For C allele or base $R s a \mathrm{I}$, restriction enzyme recognized one site at $521 \mathrm{bp}$ but not for other enzymes (Acc651 and $K p n \mathrm{I})$. For $\mathrm{T}$ allele or base, the $R s a \mathrm{I}$ recognized 2 sites (157 and $521 \mathrm{bp}$ ) and others only recognized one site at $155 \mathrm{bp}$ (Acc651) and $159 \mathrm{bp}$ (KpnI).

Restriction endonuclease of ten MC4R sequences of Bligon goat were performed in Table 3. The enzymes RsaI (GT'AC), Acc651 (G'GTAC_C), and KpnI $\left(G_{-} G T A C^{\prime} C\right)$ recognized the SNP region at position of g.1079C/T. In this study, an individual with CC genotype produced 2 fragments with enzyme RsaI and 1 fragments with Acc651 and KpnI. Individual with CT genotype produced 4 fragments with endonuclease $R s a \mathrm{I}$ and 3 fragment with Acc651 and KpnI.

\section{Phylogenetic Tree Construction}

In this study, the phylogenetic tree was constructed using Mega 5.0 based on MC4R gene of Bligon goat and corresponding sequences of goat, sheep, and cattle in GenBank. We used cattle (Bos taurus and Bos indicus) counterpart as an outgroup (Figure 5). The BLAST resulted that $\mathrm{MC} 4 \mathrm{R}$ gene of Bligon goat in

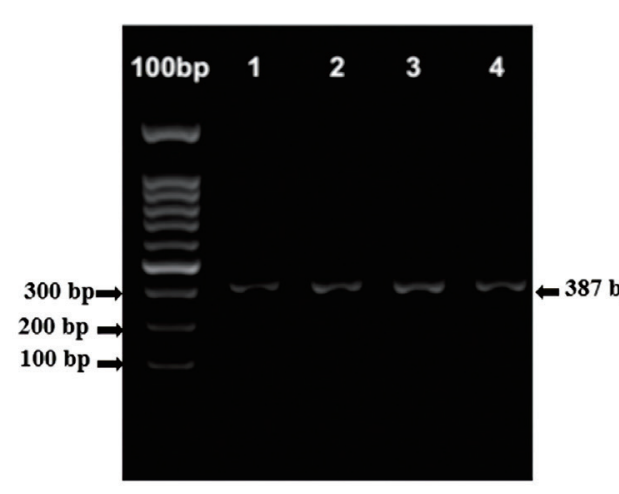

(A)

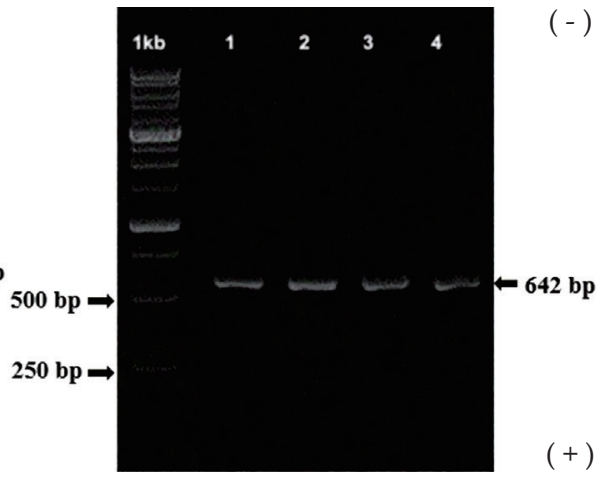

(B)

Figure 1. Agarose gel (0.8\%) showing the PCR product of MC4R gen; (A) BG1 and (B) BG2. 


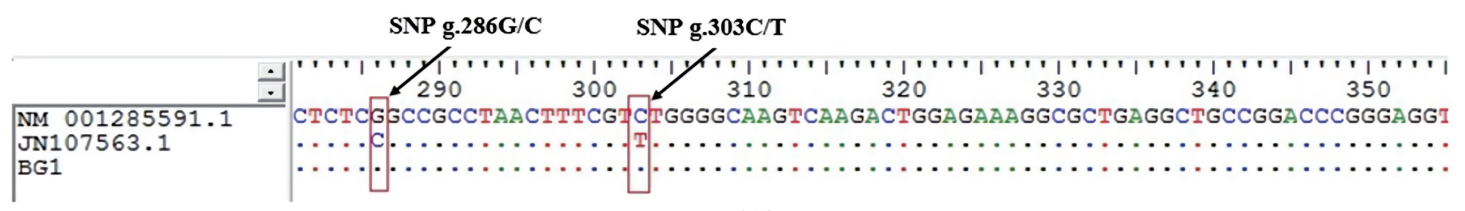

(A)

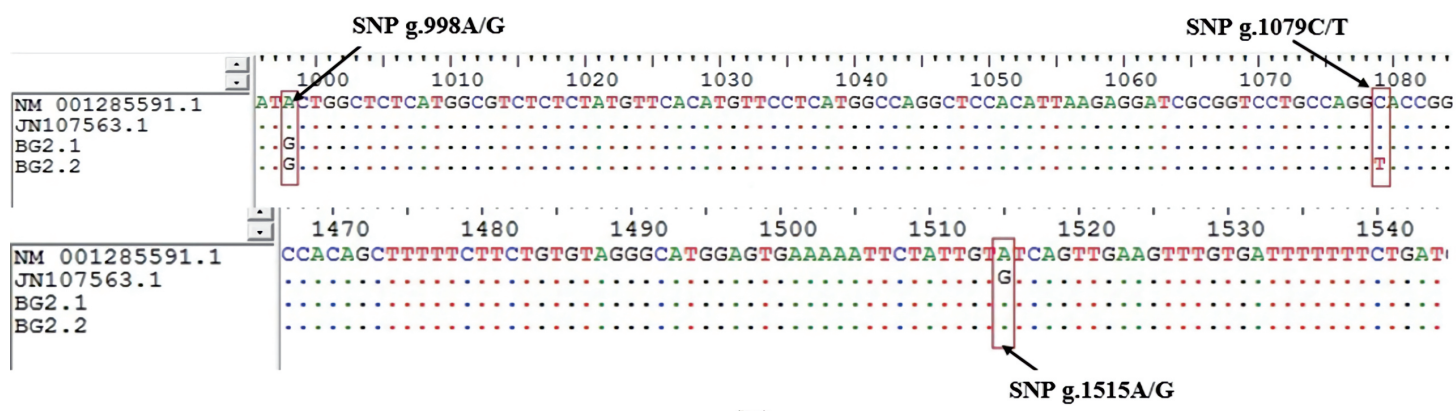

(B)

Figure 2. Multiple alignments of MC4R gene in Bligon goat compared to other goat, Genbank Acc. No. NM_001285591 and JN 107563.1; (A) BG1 and (B) BG2.

Table 2. Variations of MC4R gene in Bligon goat compared with other goat (Genbank Acc. No. NM_001285591 and JN 107563.1)

\begin{tabular}{ccccc}
\hline Region & SNP & $\begin{array}{c}\text { Bligon } \\
\text { goat }\end{array}$ & Other goat & $\begin{array}{c}\text { Amino acid } \\
\text { change }\end{array}$ \\
\hline 5'UTR & g.286G/C & G & G/C & - \\
& g.303C/T & C & C/T & - \\
Exon 1 & g.998A/G & A/G & A & Met to Ile \\
& g.1079C/T & C/T & $\mathrm{C}$ & Gly to Gly \\
& g.1515A/G & A & A/G & Ile to Met \\
\hline
\end{tabular}

BG1 and BG2 showed homologous of 99\% with Capra hircus (Acc. No. JN107563.1), 98\% with Ovies aries (Acc. No. NM_001126370.2), 95\% with Bos taurus (Acc. No. EU366349.1), and $94 \%$ and 95\% with Bos indicus (EU366350.1), respectively.
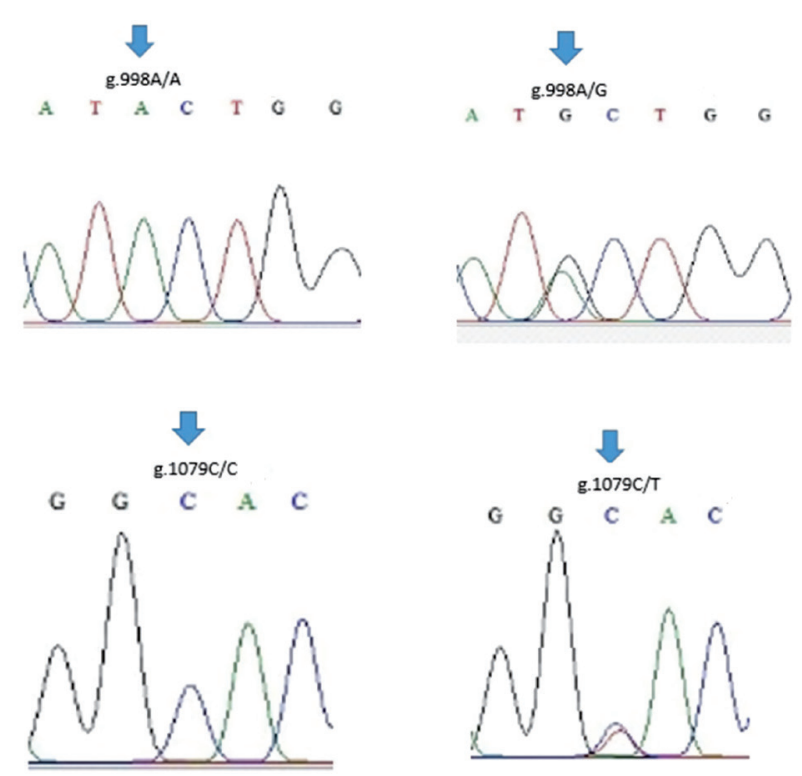

Figure 3. Partial sequence of MC4R gene in Bligon goat by DNA sequensing

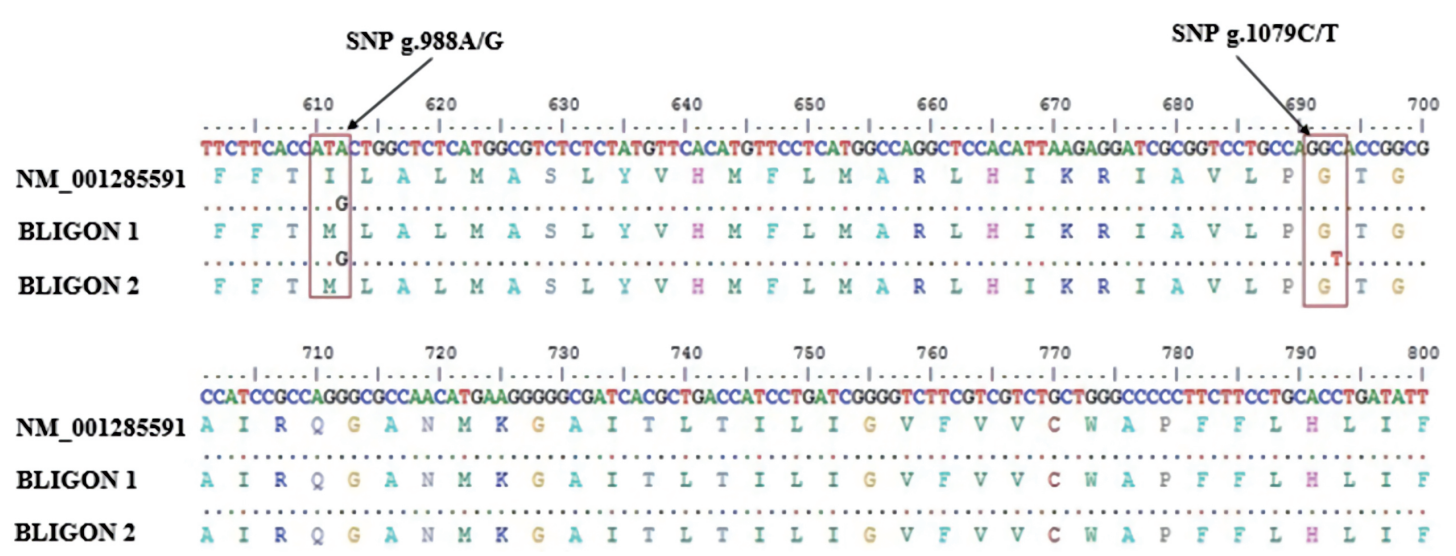

Figure 4. Amino acid change based on SNP g.988A/G and SNP g.1079C/T in two types of Bligon goat 


\section{DISCUSSION}

Melanocortin 4 Receptor (MC4R) gene, mainly expressed in the hypothalamus, is involved in the control of food intake. MC4R gene is also expressed in others tissues such as erectile tissue and is implicated in the erectile function (Dubern, 2015). The candidate gene

Table 3. Restriction enzyme mapping based on analysis using Bioedit ver 7.2.0 in two targets PCR

\begin{tabular}{|c|c|c|c|}
\hline $\begin{array}{c}\text { Restriction } \\
\text { endonuclease }\end{array}$ & SNP & $\begin{array}{c}\text { No. of } \\
\text { fragment }\end{array}$ & $\begin{array}{l}\text { Size of fragment } \\
\text { (bp) }\end{array}$ \\
\hline \multicolumn{4}{|l|}{ BG1 } \\
\hline FatI & g.286G/C & & \\
\hline \multirow[t]{2}{*}{ (‘CATG_) } & allele G & 2 & $92,131,164$ \\
\hline & allele C & 1 & 223,164 \\
\hline HaeIII & g.303C/T & & \\
\hline \multirow[t]{2}{*}{$\left(\mathrm{GG}^{\prime} \mathrm{CC}\right)$} & allele C & 3 & $106,158,50,73$ \\
\hline & allele T & 2 & $264,50,70$ \\
\hline \multicolumn{4}{|l|}{ BG2 } \\
\hline FatI & g.998A/G & & \\
\hline \multirow[t]{2}{*}{ ('CATG_) } & allele A & 7 & $\begin{array}{l}12,21,9,69,120 \\
33,306\end{array}$ \\
\hline & allele G & 8 & $\begin{array}{l}72,12,21,9,69,120, \\
33,306\end{array}$ \\
\hline NlaIII & g.998A/G & & \\
\hline \multirow[t]{2}{*}{ (_CATG') } & allele A & 7 & $\begin{array}{l}12,21,9,69,120 \\
33,302\end{array}$ \\
\hline & allele G & 8 & $\begin{array}{l}76,12,21,9,69,120, \\
33,302\end{array}$ \\
\hline RsaI & g. $1079 \mathrm{C} / \mathrm{T}$ & & \\
\hline \multirow[t]{2}{*}{$\left(\mathrm{GT}^{\prime} \mathrm{AC}\right)$} & allele C & 1 & 521,121 \\
\hline & allele T & 2 & $157,364,121$ \\
\hline Acc651 & g.1079C/T & & \\
\hline \multirow[t]{2}{*}{ (G'GTAC_C) } & allele C & - & 642 \\
\hline & allele T & 1 & 155,482 \\
\hline KpnI & g.1079C/T & & \\
\hline \multirow[t]{2}{*}{ (G_GTAC'C) } & allele C & - & 642 \\
\hline & allele $\mathrm{T}$ & 1 & 159,477 \\
\hline
\end{tabular}

approach is efficient in revealing genomic regions and specific markers in livestock. Four variations of MC4R gene in the promoter region were detected in bovine (Zhang et al., 2009). Liu et al. (2010) reported that five SNPs in 5'UTR and one SNP in exon were identified in the $5^{\prime}$ untranslated region of cattle $(-129 \mathrm{~A} / \mathrm{G})$. In other studies, four SNPs were observed in the 3'untranslated region of $\mathrm{Hu}$ Sheep MC4R by PCR-SSCP and DNA sequencing.

In this study, there was no polymorphism detected in the $387 \mathrm{bp}$ fragment of MC4R gene of Bligon goat (BG1). However, we discovered 2 SNPs MC4R gene in 5 'UTR region when we compared the sequence of MC4R gene of Bligon goat with 2 GenBank from NCBI. This study indicated that sequence of MC4R gene of Bligon goat was different from the other sequences of goat, sheep, and cattle in BG1. The conclusion of this study is MC4R gene in this region may be used to distinguish Bligon goat from the other specieses. Zuo et al. (2014) reported one SNP in g.1016G/A. According to the result of MC4R Polymorphism by Song et al. (2012), four SNPs (g.1016G/A, g.1240T/C, g.1264G/A, and g.1325A/G) were located in non-coding region. Non-coding sequences are important for regulatory functions. Mignone et al. (2002) reported an untranslated region that controls their translation, degradation, and localization include stemloop structures, upstream initiation codons and open reading frames, internal ribosome entry sites, and various cis-acting elements that are bound by RNA-binding proteins.

Our results detected 2 SNP in exon region and an SNP was identified when we compared to GenBank (BG2). Two SNPs found in Bligon goat was not detected at 2 GenBank in our study. Several studies detected SNP in exon region of MC4R gene. Two SNPs were detected at $946 \mathrm{~A} / \mathrm{C}$ and $986 \mathrm{C} / \mathrm{T}$ in Boar goat (Jun et al., 2013). Zou et al. (2014) identified one synonymous substitution at 93G/A changed a codon GGG to AGG (proline) suggesting a synonymous substitution because they encode the same amino acid and one non-synonymous at 293G/A changed amino acid glysine to arginine. In Simmental bull, SNP of MC4R gene in locus 1069C/G was detected by DNA pool sequencing analysis (Du et al., 2013).

Tabel 4. Three recommended restriction enzymes based on SNP g.1079C/T

\begin{tabular}{|c|c|c|c|c|c|c|c|c|}
\hline \multirow{3}{*}{ No } & \multirow{3}{*}{ Sample code } & \multicolumn{6}{|c|}{ Restriction enzyme } & \multirow{3}{*}{ Genotype } \\
\hline & & \multicolumn{2}{|r|}{ RsaI (GT'AC) } & \multicolumn{2}{|c|}{ Acc651 (G'GTAC_C) } & \multicolumn{2}{|c|}{ KpnI ( G_GTAC'C) } & \\
\hline & & Site & Fragment & Site & Fragment & Site & Fragment & \\
\hline 1 & K3.1 & 1 & 521,121 & 0 & 642 & 0 & 642 & homozygous CC \\
\hline 2 & K5.1 & 1 & 521,121 & 0 & 642 & 0 & 642 & homozygous CC \\
\hline 3 & K11.1 & 1 & 521,121 & 0 & 642 & 0 & 642 & homozygous CC \\
\hline 4 & K12.1 & 1 & 521,121 & 0 & 642 & 0 & 642 & homozygous CC \\
\hline 5 & K15.2 & 2 & $157,364,121,642$ & 1 & $155,482,642$ & 1 & $159,477,642$ & heterozygous CT \\
\hline 6 & K19.1 & 2 & $157,364,121,642$ & 1 & $155,482,642$ & 1 & $159,477,642$ & heterozygous CT \\
\hline 7 & K25.1 & 2 & $157,364,121,642$ & 1 & $155,482,642$ & 1 & $159,477,642$ & heterozygous CT \\
\hline 8 & K33.1 & 1 & 521,121 & 0 & 642 & 0 & 642 & homozygous CC \\
\hline 9 & K34.1 & 1 & 521,121 & 0 & 642 & 0 & 642 & homozygous CC \\
\hline 10 & K24.1 & 1 & 521,121 & 0 & 642 & 0 & 642 & homozygous CC \\
\hline
\end{tabular}




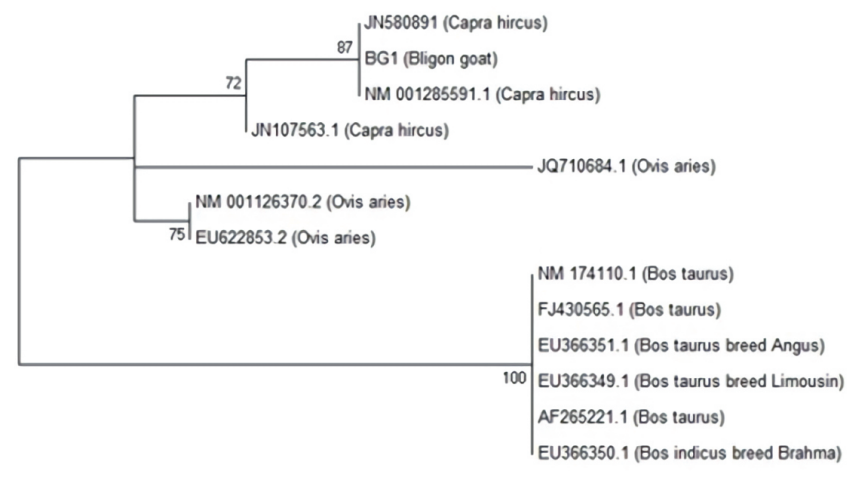

(A)

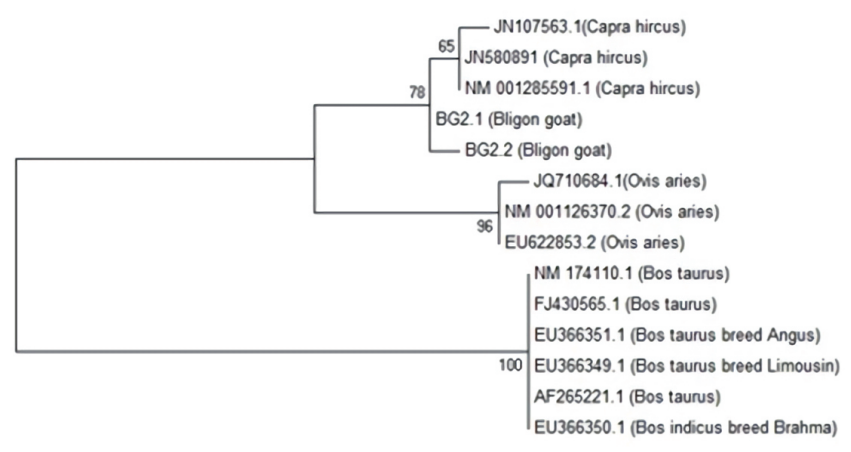

$\longmapsto 0.0050$

Figure 5. Phylogenetic tree based on partial MC4R gene; (A) BG1 and (B) BG2.

Five single nucleotide polymorphisms were located in $273 \mathrm{C}>\mathrm{T}, 321 \mathrm{G}>\mathrm{T}, 864 \mathrm{C}>\mathrm{A}, 1069 \mathrm{G}>\mathrm{C}$, and $1206 \mathrm{G}>\mathrm{C}$ in Maiwa yak population $(n=354)$. The missense mutation at position $1069 \mathrm{G}>\mathrm{C}$ suggesting there is a change in MC4R amino acid. Four haplotypes (TGCGG, CGCGG, CGACG and CTCCC) were reported by Cai et al. (2015).

Based on SNP analysis of the nucleotide, it was found that g.306G/A and g.706C/A were identified in the coding region (Wang et al., 2015). In other species, 1426G/A MC4R gene mutation were found in pig (Piorkowska et al., 2010). Six SNP were detected in c.780C/G, c.135C/T, с.175C/T, c.707G/A, c.898C/A, and c.430A/T (Fontanesi et al., 2013). Deng et al. (2016) reported eight SNPs were located in MC4R gene of buffalo. The SNP in location g.345A/G, g.762G/A, g.864G/T, and g.1104C/T were located in the exon region and were synonymous mutations and SNP in g.138A/G and g.226C/T, g.1340T/G and g.1525A/G were identified in the 5'untranslated region (UTR) or 3'-UTR. The present study on MC4R gene in Bligon goat described here provided a basis for future research in MC4R gene of Bligon goat.

In our study, three restriction endonucleases (RsaI, Acc651, and KpnI ) can be used for genotyping of Bligon goat using PCR-RFLP method. The RsaI, Acc651, and KpnI recognized GT'AC, G'GTAC_C, and G_GTAC'C; respectively. According to Williams (2003), the restriction enzyme is a fundamental tool of molecular biology for diversity and in vivo function. Previous research used restriction enzyme for genotyping mammals was based on MC4R gene (Liu et al., 2010; Wang et al., 2015). Wang et al. (2015) reported that restriction enzyme MspI, Kpn2I and NdeI were used for genotyping mammals. In other study, enzyme Tail was used for PCR-RFLP and produced three genotypes in a Qinchuan cattle (Liu et al., 2010).

Phylogenetic research on the domestic goat and other species usually used mtDNA region and $C y t b$ gene. Based on the previous study, mtDNA region and Cyt $b$ gene have explored the taxonomic relationship among goat and other species (Pakpahan et al., 2015, Pakpahan et al., 2016). In this study, phylogenetic tree was constructed based on MC4R gene of Bligon goat and several sequences of Capra hircus, Ovies aries, Bos taurus, and Bos indicus. The Bligon goat and C. hircus in the phylogentic tree were joined first, followed by the $O$. aries and then $B$. taurus and $B$. indicus.

\section{CONCLUSION}

The present study of MC4R gene in Bligon goat detected non-synonymous polymorphism in location g.998A/G which changed amino acid methionine (Met) to isoleucine (Ile) and the SNP at g.1079C/T was a synonymous polymorphism. Restriction endonucleases RsaI, Acc651, and KpnI may be used for genotyping Bligon goat using PCR-RFLP method in the future research. The SNP of MC4R gene in Bligon goat described here provided a basis for future research of the potential genetic marker.

\section{ACKNOWLEDGEMENT}

The study was supported by the grant from Indonesia Higher Education (Dikti) in PMDSU (Master Program of Education Leading to Doctoral Degree for Excellent Graduates) program scheme with contract no. 4587/UN1-P.III/LT/DIT-LIT/2016. Also, thank to Retno Setyawati for helping DNA analysis.

\section{REFERENCES}

Cai, X., T. D. Mipam, F. F. Zhao, \& L. Sun. 2015. SNPs detected in the yak MC4R gene and their association with growth traits. J. Animal. 9: 1097-1103. https://doi.org/10.1017/ S1751731115000397

Deng, T. X., C. Y. Pang, M. Q. Liu, C. Zhang, \& X. W. Liang. 2016. Synonymous single nucleotide polymorphisms in the MC4R gene that are significantly associated with milk production traits in water buffaloes. J. Gen. Mol. Res. 15:18. https://doi.org/10.4238/gmr.15028153

Du, X. H., C. Chen, Z. R. Yuan, L. M. Zhang, X. J. Chen, Y. H. Wang, X. Gao, L. P. Zhang, H. J. Gao, J. Y. Li, \& S. Z Xu. 2013. Genetic polymorphisms of MC4R and IGF2 gene association with feed conversion efficiency traits in beef cattle. J. Vet., 33: 418-422.

Dubern, B. 2015 MC4R and MC3R Mutations. In M.L. Frelut (Ed.), The ECOG's eBook on Child and Adolescent Obesity. 
Available at ebook.ecog-obesity.eu. [9 February 2016].

Fontanesi, L., L. Buttazzoni, G. Galimberti, D.G. Calo, E. Scotti, \& V. Russo. 2013. Association between Melanocortin 4 Receptor (MC4R) gene haplotypes and carcass and production traits in Italian Large White pigs evaluated with a selective genotyping approach. J. Livestock. Sci. 157:48-56. https://doi.org/10.1016/j.livsci.2013.07.006

Galve A., C. Burgos, L. Silio, L. Varona, C. Rodríguez, C. Ovilo, \& P. Lopez-Buesa. 2012. The effects of Leptin Receptor (LEPR) and Melanocortin-4 Receptor (MC4R) polymorphisms on fat content, fat distribution and fat composition in a Duroc $\times$ Landrace/Large White cross. J. Livestock. Sci. 145: 145-152. https://doi.org/10.1016/j.livsci.2012.01.010

Gregorio, P. D., A. D. Trana, P. Celi, S. Claps, \& A. Rando. 2014. Comparison of goat, sheep, cattle and water buffalo leptin (LEP) genes and effect of the intron 1 microsatellite polymorphism in goat. Anim. Prod. Sci. 54: 1258-1262. https://doi.org/10.1071/an14101

Hartatik, T. 2014. Analisis Genetik Ternak Lokal. Gadjah Mada University Press. Yogyakarta: 75-88.

Hartatik, T. 2016. Pendekatan Praktis Deteksi Polimorfisme DNA Sapi Aceh. Gadjah Mada University Press. Yogyakarta:118-134.

Jun, Z., Q. Yong, Z. Sheng, C. Hua, W. H. Li, L.Y. Xia, \& C. S. Xian. 2013. Single nucleotide polymorphisms of gene fragment of melanocortin receptor-4 C-terminal and its association with body weight in Boer goats. Jiangsu J. Agr. Sci. 6. (Abstract).

Kimura, M. 1980. A simple method for estimating evolutionary rates of base substitutions through comparative studies of nucleotide sequences. J. Mol. Evol. 16: 111-120. https://doi. org/10.1007/BF01731581

Liu, H., W. Tian, L. Zang, H. Wang, \& H. Cui. 2010. Mutations of MC4R gene and its association with economic traits in Qinchuan cattle. J. Mol. Biol. Rep. 37:535-540. https://doi. org/10.1007/s11033-009-9706-0

Mignone F., C. Gissi, \& S. Liuni. 2002. Untranslated regions of mRNAs (Review). Gen. Bio. 3:1-10.

NCBI. 2015. MC4R melanocortin 4 receptor Capra hircus (goat). Availabel at http://www.ncbi.nlm.nih.gov/ gene/?term=mc4r\%2C+goat. [13April 2016].

Pakpahan, S., W. T. Artama, R. Widayanti, \& I. G. Suparta. 2015. Genetic variations and the origin of native Indonesian goat breeds based on mtDNA D-Loop sequences. Asian J. Anim.
Sci. 9 : 341-350. https://doi.org/10.3923/ajas.2015.341.350

Pakpahan, S., W. T. Artama, \& I. G. Suparta. 2016. Genetic characteristics and relationship in different goat populations of Indonesia based on Cytochrome B gene sequences. Asian J. Anim. Sci. 10: 29-38. https://doi.org/10.3923/ajas.2016.29.38

Piorkowska, K., M. Tyra, M. Rogoz, K. R. Molik, M. Oczkowicz, \& M. Rozycki. 2010. Association of the melanocortin-4 receptor (MC4R) with feed intake, growth, fatness and carcass composition in pigs raised in Poland. J. Meat Sci. 85: 297-301. https://doi.org/10.1016/j.meatsci.2010.01.017

Schroyen, M., S. Janssens, A. Stinckens, M. Brebels, F. Bertolini, C. Lamberigts, K. Bekaert, L. Vanhaecke, M. Aluwe, F.A.M. Tuyttens, S. Millet, \& N. Buys. 2015. The MC4R c.893G>A mutation: A marker for growth and leanness associated with boar taint odour in Belgian pig breeds. J. Meat Sci. 101: 1-4. https://doi.org/10.1016/j. meatsci.2014.08.009

Seong, J., S. S. Dong, D. P. Kyung, K. L. Hak, \& S. K. Hong. 2011. Identification and analysis of MC4R polymorphisms and their association with economic traits of Korean cattle (Hanwoo). J. Mol. Biol. Rep. 39: 3597-3601. https://doi. org/10.1007/s11033-011-1133-3

Song, X. M., J. F. Jiang, G. Z. Zhang, F. X. Shiand, \& Y. Q. Jiang. 2012. DNA polymorphisms of the Hu sheep melanocortin-4 receptor gene associated with birth weight and 45-day weaning weight. J. Gen. Mol. Res. 11: 4432-4441. https://doi.org/10.4238/2012.September.27.3

Wang, Y., C. Wang, J. Zhang, C. Meng, X. Zhang, Z. Wang, Y. Fang, D. Mao, \& S. Cao. 2015. Three novel MC4R SNPs associated with growth traits in Hu sheep and East Friesien x Hu crossbreed sheep. Small Rum. Res. 125: 26-33. https:// doi.org/10.1016/j.smallrumres.2015.02.007

Williams, R. J. 2003. Review: Restriction endonucleases. J. Mol. Biotec. 23: 225-243. https://doi.org/10.1385/MB:23:3:225

Zhang, C., Y. H. Wang, H. C. X. Y. Lan, C. Z. Lei, \& X. T. Fang. 2009. Association between variants in the $5^{\prime}$-untranslated region of the bovine MC4R gene and two growth traits in Nanyang cattle. J. Mol. Biol. Rep. 36:1839-1843. https://doi. org/10.1007/s11033-008-9388-z

Zuo, B., G. Liu, Y. Peng, H. Qian, J. Liu, X. Jiang, \& A. Mara. 2014. Melanocortin-4 receptor $(M C 4 R)$ polymorphisms are associated with growth and meat quality traits in sheep. J. Mol. Biol. Rep. 41: 6967-6974. https://doi.org/10.1007/ s11033-014-3583-x 